Prepared for the U.S. Department of Energy under Contract DE-AC05-76RL01830

\title{
Wet Gasification of Ethanol Residue: A Preliminary Assessment
}

MD Brown

DC Elliott

December 2008

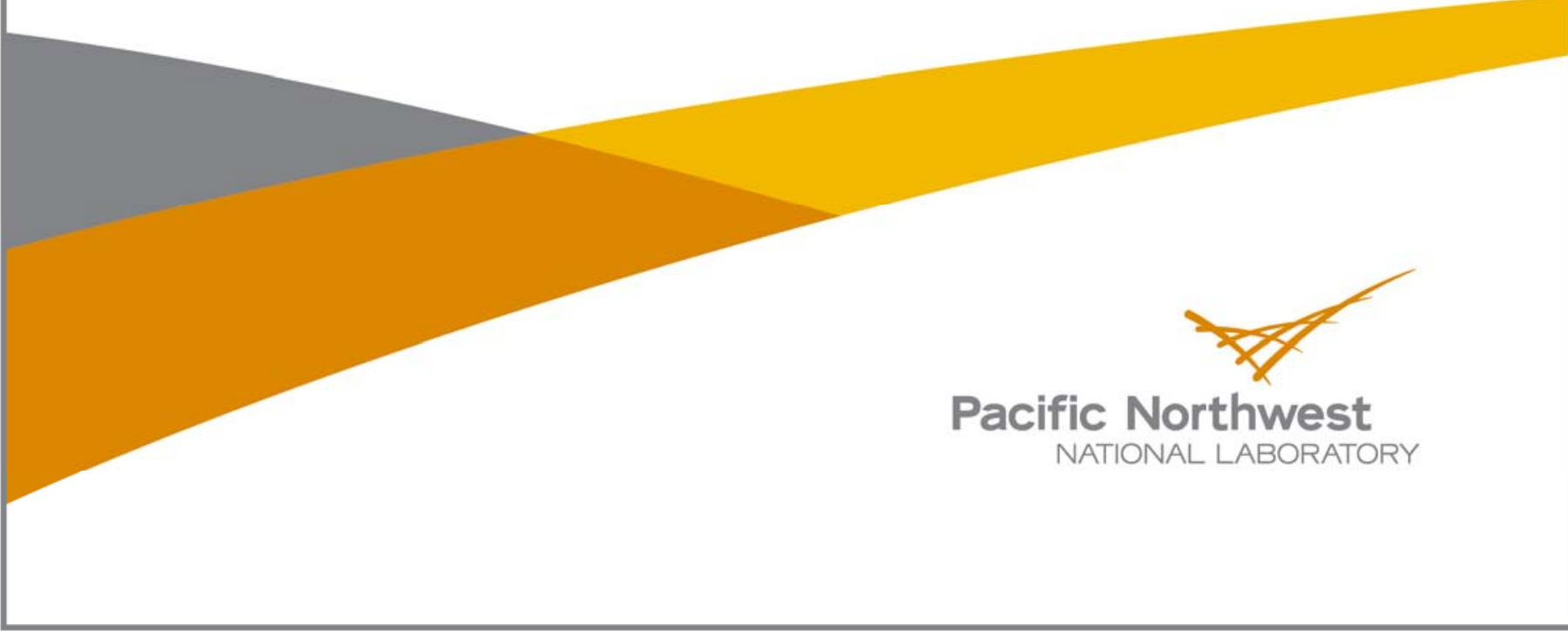




\title{
DISCLAIMER
}

This report was prepared as an account of work sponsored by an agency of the United States Government. Neither the United States Government nor any agency thereof, nor Battelle Memorial Institute, nor any of their employees, makes any warranty, express or implied, or assumes any legal liability or responsibility for the accuracy, completeness, or usefulness of any information, apparatus, product, or process disclosed, or represents that its use would not infringe privately owned rights. Reference herein to any specific commercial product, process, or service by trade name, trademark, manufacturer, or otherwise does not necessarily constitute or imply its endorsement, recommendation, or favoring by the United States Government or any agency thereof, or Battelle Memorial Institute. The views and opinions of authors expressed herein do not necessarily state or reflect those of the United States Government or any agency thereof.

\author{
PACIFIC NORTHWEST NATIONAL LABORATORY \\ operated by \\ BATTELLE \\ for the \\ UNITED STATES DEPARTMENT OF ENERGY \\ under Contract DE-AC05-76RL01830
}

Printed in the United States of America
Available to DOE and DOE contractors from the Office of Scientific and Technical Information,
P.O. Box 62, Oak Ridge, TN 37831-0062;
ph: (865) 576-8401
fax: $(865)$ 576-5728
email: reports@adonis.osti.gov

\begin{abstract}
Available to the public from the National Technical Information Service, U.S. Department of Commerce, 5285 Port Royal Rd., Springfield, VA 22161 ph: (800) 553-6847 fax: $(703) 605-6900$ email: orders@ntis.fedworld.gov online ordering: http://www.ntis.gov/ordering.htm
\end{abstract}

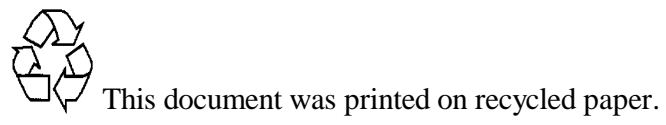




\section{Wet Gasification of Ethanol Residue}

\section{A Preliminary Assessment}

MD Brown

DC Elliott

December 2008

Prepared for the U.S. Department of Energy under Contract DE-AC06-76RL01830

Pacific Northwest National Laboratory

Richland, WA 99352 


\section{Contents}

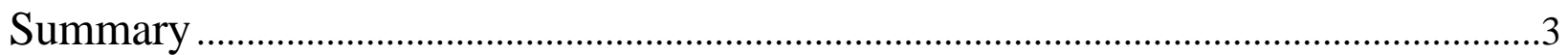

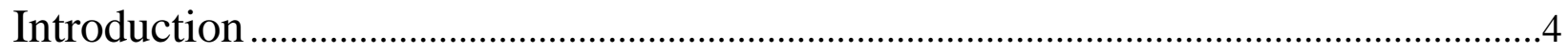

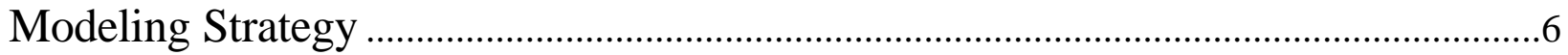

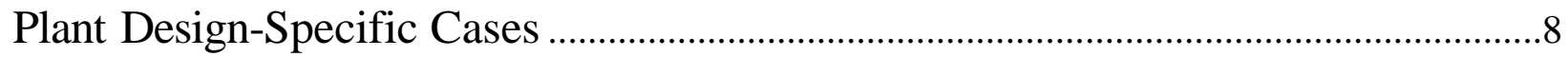

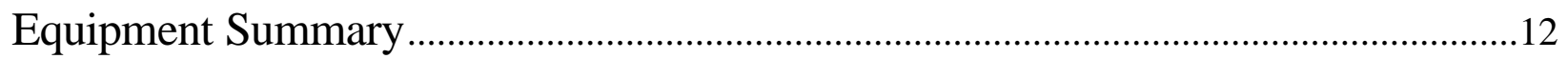

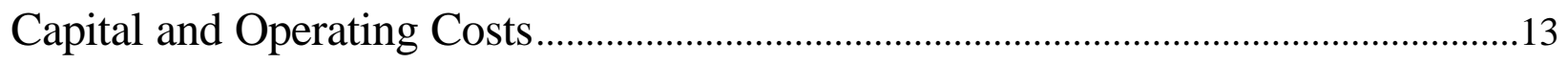

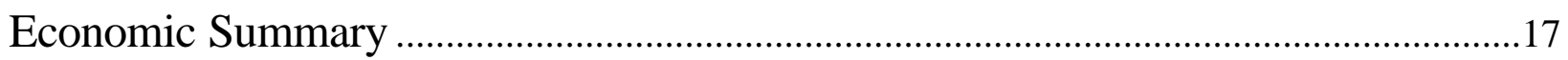

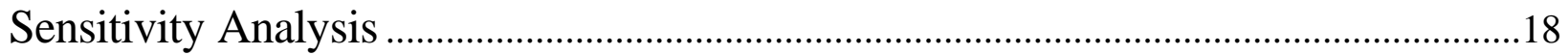




\section{Summary}

This report summarizes work that was done during the summer of 2003 to evaluate the potential for wet gasification to contribute to waste treatment and energy balance issues associated with ethanol production from starch or biomass feedstocks.

The work consisted of updating an existing EXCEL spreadsheet (originally developed at PNNL) which provided a simple economic design model of wet gasification and evaluating a total of six case studies involving a variety of feed streams in both conventional corn-based and lignocellulosic-based ethanol production facilities. The six cases are:

1. DDG\&S-PNNL. This initial case involved the expansion of the original spreadsheet to include equipment costing and economic evaluation using standard chemical engineering methods and conventions (Peters \& Timmerhaus). The original feedstock was distillers dried grain and solubles (DDG\&S) from a starch-based ethanol plant at 5600 wet tons/day and $11 \%$ solids. This corresponds to a fairly large ethanol facility (about 40 million gal/year).

2. DDG\&S-NREL. This case is the base case for DDG\&S. This is the PNNL model described above scaled to a feed rate of 2100 wet tons DDG\&S/day. According to NREL this corresponds to the ir 25 million gal ethanol/year model. This model also incorporated a sensitivity analysis on profitability for a range of plant sizes (20-100 million gal/yr), cost of DDG\&S ( $\$ 8$ to $+\$ 4 /$ wet ton), and natural gas prices.

3. LIGNIN. This case uses the residual (waste lignin) stream from a lignocellulosic ethanol plant processing 2000 tonne/day of corn stover according to the NREL model. The actual lignin feed stream is 8033 wet tons/day at $15.7 \%$ solids.

4. SYRUP. This case uses the concentrated lignocellulosic-derived syrup from the same NREL model after the evaporators as feedstock. This is a concentrated feed stream at 1056 wet tons/day and $40 \%$ solids.

5. WWT. This would replace the anaerobic and aerobic digesters in the wastewater treatment section of the above NREL model. This is a highly dilute water stream with very limited solids. The feedstock is 2573 wet tons/day at only $1.2 \%$ solids.

6. TOTALB2E. This would take the entire bottoms from the distillation columns in the above NREL model at 21,888 wet tons/day and $13.7 \%$ solids. This could eliminate the high cost evaporation train and a variety of downstream capital equipment, but not without several other potential flowsheet complications.

In summary, each of the above cases can produce viable quantities of substitute natural gas (SNG) for in-plant use or outside sales. However, it becomes an economic trade-off between the value of DDG\&S to the cattle feeder and the cost of natural gas at the pipeline. If DDG\&S becomes essentially worthless (cost of disposal) and natural gas rises above $\$ 7.50$ per million $\mathrm{Btu}$, then wet gasification becomes quite attractive at reasonable plant sizes. 


\section{Introduction}

Ethanol is a major commodity chemical in the world, used for a variety of chemical, industrial and food uses. One of the largest uses in the U.S. is in blending for motor fuels, with nearly 1.5 billion gallons used in 1999. Most ethanol in the U.S. is produced as a fermentation product of the corn milling or other starch-based industries.

In an effort to make ethanol more competitive as an oxygenator and octane booster, the U.S. Department of Energy is examining ways to produce ethanol more efficiently, to effectively treat and recover additional energy in the waste streams, and to produce it from waste lignocellulosic feedstocks.

One technology that has potential application towards treating and recovering energy from dilute waste streams is wet gasification. In this process, shown in Figure 1 and further described by Elliott et al. (1999), dilute organic streams are converted to methane over catalysts under near supercritical water conditions. The processing conditions are such that high-moisture waste streams can be treated without the substantial energy penalty associated with vaporizing the water. This analysis does not address any of the process development issues surrounding the wet gasification process. It assumes that the process is commercial, that catalyst is commercially available in large quantities, and that catalyst lifetimes are adequate.

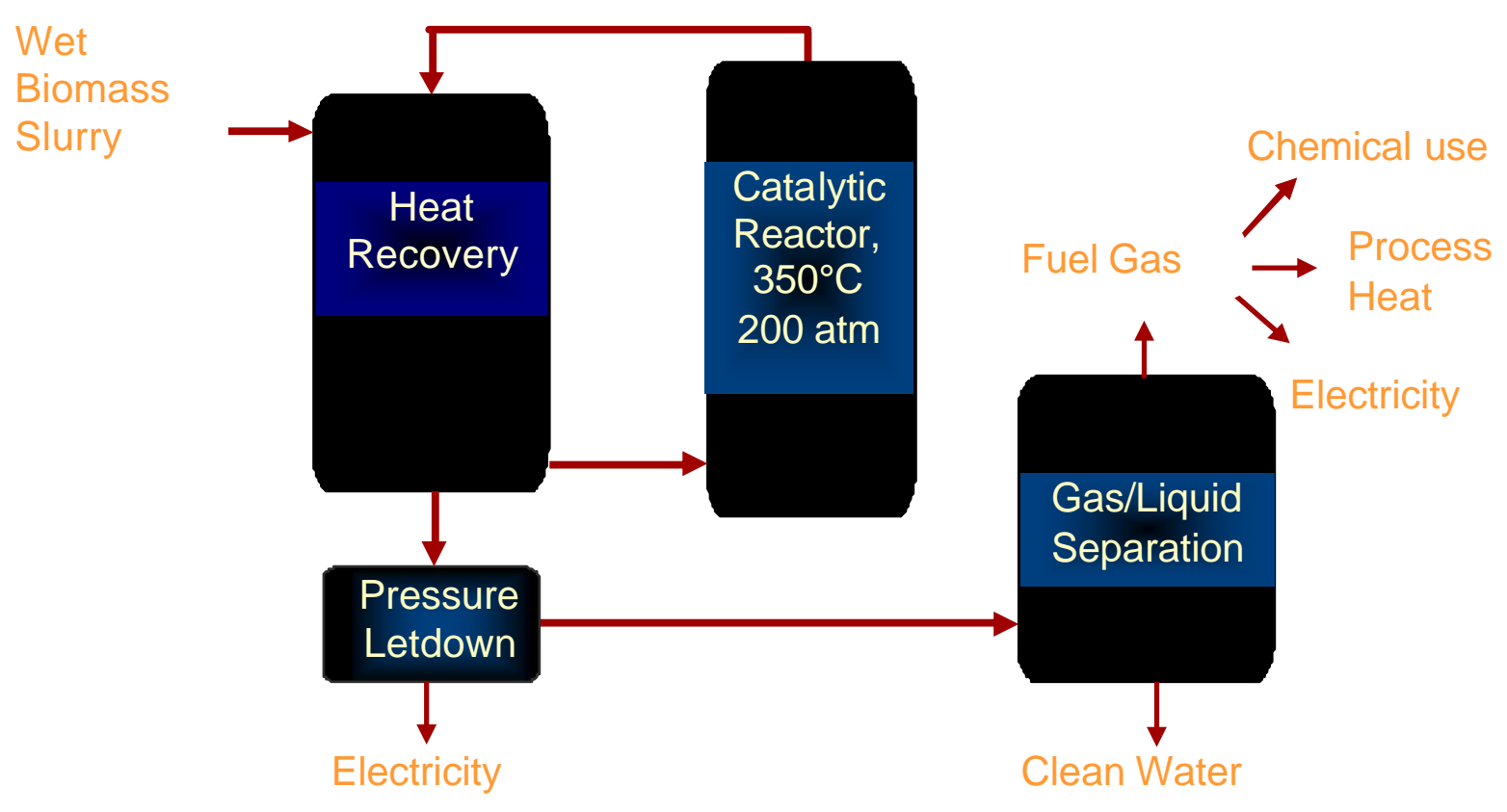

Figure 1. Typical wet gasification process

By far the largest byproduct of the corn-based ethanol process is distillers dried grain and solubles (DDG\&S), which correspond to nearly a third of the input corn. When the DDG\&S can be sold profitably as cattle feed, it provides a large revenue stream that contributes positively to 
the selling price of the ethanol product. However, if the cattle feed market is highly depressed, it can become a waste stream liability. Wet gasification can potentially treat this waste stream to generate a synthetic natural gas (SNG), which can be burned in the boilers and offset the purchase of other fuels used to generate heat for the distillation process. The initial case considered in this analysis was the conversion of 5600 tons per day of DDG\&S. A second case scaled to the NREL model at 2100 tons per day of DDG\&S was also considered. These cases are further developed and outlined in the modeling section of this report.

The National Renewable Energy Laboratory (NREL) has continued to evaluate the potential for conversion of other lignocellulosic biomass streams to ethanol. They have focused primarily on the critical conversion of cellulose and hemicellulose to sugars and have had some success in improving the enzymatic and acid hydrolysis steps necessary for these conversions. While ethanol from lignocellulosics is still not cost competitive, important steps are being taken to model and evaluate potential flowsheets that can improve these economics. Several waste streams within these flowsheets could be candidates for wet gasification. These have been considered in four separate cases for treating the waste lignin stream, a concentrated syrup stream, a dilute wastewater stream, and the entire distillation column bottoms stream. Each of these cases is further outlined and discussed in the modeling section of this report. 


\section{Modeling Strategy}

The modeling strategy for this analysis involves the embellishment of an existing EXCEL spreadsheet model that calculates heat and material balances around a wet gasification reactor. The model begins with a design basis and flowsheets, calculates specific stream data, summarizes the baseline unit operations equipment list, calculates the baseline equipment costs, calculates the total capital investment, summarizes the annual operating costs, and conducts a sensitivity analysis.

Cost estimating for chemical plants is typically carried out in several steps as outlined in Figure 2. These methods are time-tested by decades of chemical plant engineers and are well documented in Peters and Timmerhaus (1968).

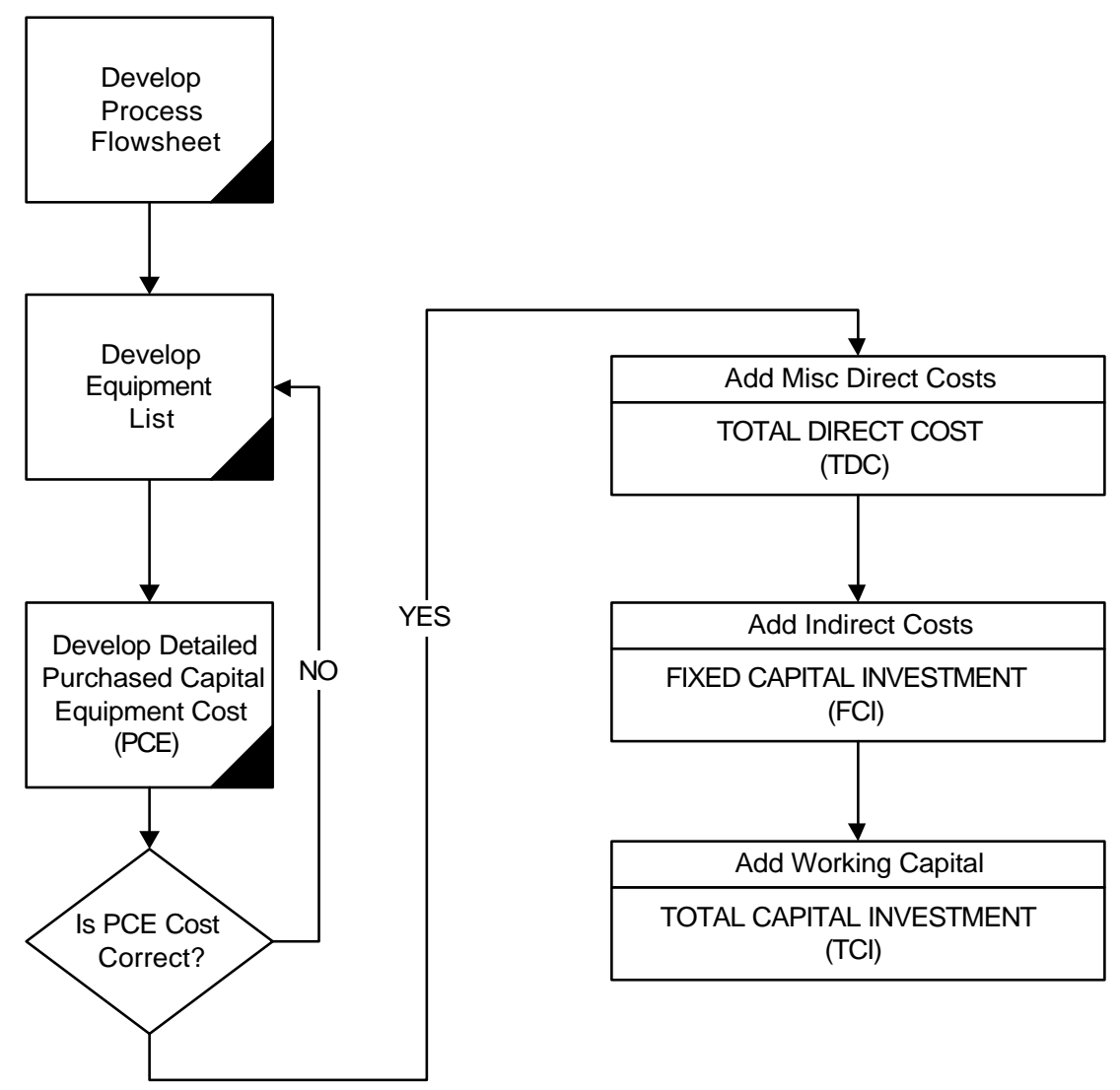

Figue 2. Cost estimating strategy

First, purchased capital equipment costs are developed from an equipment list generated from the flowsheet. Secondly, a series of direct costs, such as equipment installation, piping, instrumentation, etc., are scaled from the purchased equipment costs to fold into total direct costs (TDC), which is about $70 \%$ of the fixed capital investment (FCI). Finally, a number of indirect costs such as engineering, construction expenses, and contingency are scaled from TDC and 
summed to total indirect costs (TIC). The FCI is the sum of the direct and indirect costs of construction. The total capital investment (TCI) typically includes a 10-20\% adder for estimated working capital.

These costs are rolled up into an economic analysis where a Return on Investment (ROI) is calculated for each case. In addition, a break-even gas cost is calculated based on the TIC of the improvement. 


\section{Plant Design-Specific Cases}

Six specific design cases were considered in this initial analysis. Each of these cases has considered only the economics of a stand-alone wet gasification system based on the specific feedstock. These analyses do not consider any benefits of co-location, new construction, or retrofits.

\section{DDG\&S-PNNL Case}

This case is the initial case considered in the evaluation. This case took the original EXCEL spreadsheet and modeled a wet gasification system employing a feed stream of 5600 wet tons of DDG\&S per day. The wet gasification system employed in this case requires a Total Capital Investment of about $\$ 41 \mathrm{M}$ with $\$ 8 \mathrm{M}$ of this being purchased equipment. Operating costs are expected to be about $\$ 11 \mathrm{M}$, for a breakeven gas cost of $\$ 3.92 / \mathrm{MMBtu}$.

\section{DDG\&S-NREL Case}

This case is the baseline case for the analysis and is based on the PNNL model. All tables in the ensuing sections are derived from this case. The PNNL model was scaled to a feedsteam of 2100 wet tons per day of DDG\&S, which corresponds to the byproduct stream from a $25 \mathrm{MM}$ gallon/year starch-based ethanol plant according to the USDA model.

The design basis values are shown in the table below and are lifted directly from the EXCEL model.

Table 1. Process parameters for DDG\&S-NREL case

\begin{tabular}{|c|c|c|}
\hline Feedrate, Tons/day wet basis & 2100 & \\
\hline wt $\%$ organic solids & $10.5 \%$ & \\
\hline wt\% organic solids fed to plant & $10.5 \%$ & 140,700 ppm COD \\
\hline Feedrate, gal/day & 450,719 & \\
\hline Operating Hours per year & 8,000 & \\
\hline Feedrate, Mlb/yr dry organic solids & 147.00 & \\
\hline SCF gas per lb dry solids & 11.8 & $86.37 \mathrm{gas} \mathrm{l} / \mathrm{I}$ feed \\
\hline cubic meters per kg dry solids & 0.74 & \\
\hline Total SCF per day & 5203800 & $4,163,040$ \\
\hline BTU per SCF & 600 & \\
\hline Gas yield, BTU/lb dry solids & 7080 & \\
\hline MBTU per day & 3122 & \\
\hline Medium BTU gas, MBTU per year & 1040760 & $1,096,961 \mathrm{GJ} / \mathrm{yr}$ \\
\hline
\end{tabular}

The actual equipment list, fixed and total capital investment, operating costs, and a full economic analysis for this case are completely given in the ensuing sections. 


\section{$\underline{\text { LIGNIN Case }}$}

This is the first of several cases which are based on the lignocellulosic to ethanol model being developed by NREL. This model uses corn stover as the original lignocellulose feedstock, which is hydrolyzed to sugars via acid or enzymatic hydrolysis. The actual feed for the wet gasification process in this case is the bottoms from their initial evaporation column (Stream 525 on NREL PFD-P110-A505). This will be 8033 wet tons per day at $15.7 \%$ solids. This stream contains the insoluble solids and syrup out of the bottom of the beer distillation column after it has gone through the first evaporation column. This would eliminate the need for two additional stages of evaporation, a filter press, and associated transport and storage. Presumably it would also simplify the combustion side as well because only gases would be burned.

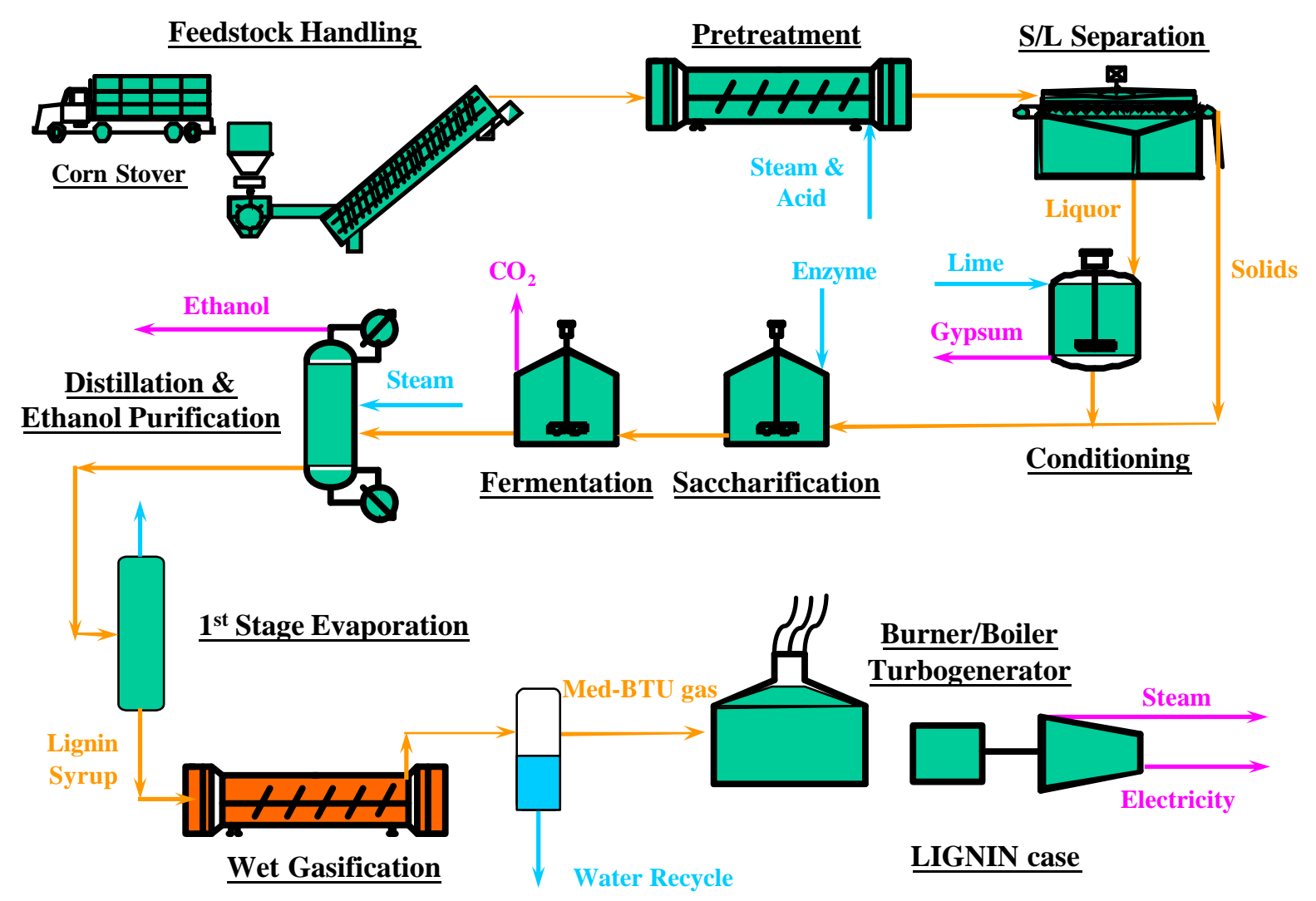

Figure 3. Flow schematic of the LIGNIN case

Installation of a wet gasification train in the LIGNIN case requires an installed equipment cost of just over $\$ 10 \mathrm{M}$, requiring a Total Capital Investment (TCI) of $\$ 60 \mathrm{M}$. Annual operating costs are expected to be about $\$ 14 \mathrm{M}$. Break-even gas costs are expected to be about $\$ 2.20 / \mathrm{MMBtu}$. 


\section{$\underline{\text { WWT Case }}$}

This case replaces the anaerobic and aerobic wastewater treatment systems currently specified in the NREL design with wet gasification. The feed stream is Stream 612 (NREL PFD-P110A601) and is 2573 wet tons per day at $1.2 \%$ solids.

Integration of this wet gasification train into the existing NREL flowsheet would involve about $\$ 5 \mathrm{M}$ in purchased equipment and a Total Capital Investment of $\$ 29 \mathrm{M}$. Annual operating costs would be about $\$ 6.7 \mathrm{M}$, generating a breakeven gas cost of over $\$ 40 / \mathrm{MMBtu}$. The cost of this modification would have to be evaluated against the actual investment required for both anaerobic and aerobic wastewater treatment systems to determine the feasibility.

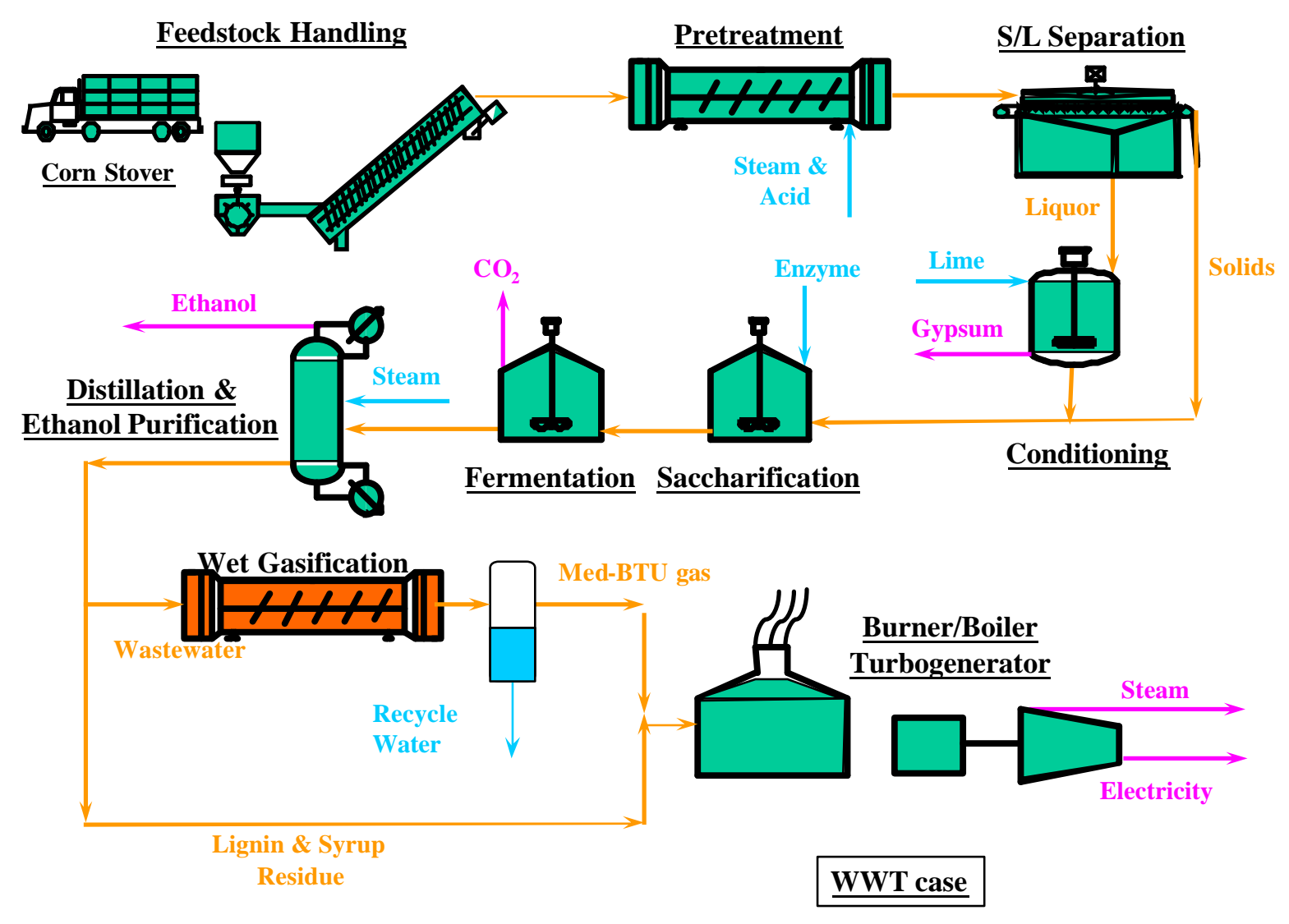

Figure 4. Flow schematic of the WWT case

\section{TOTALB2E Case}

This case examines the effect of taking the entire bottoms stream from the distillation columns (Stream 518A on NREL PFD P110-A504) and immediately converting it to synthetic natural gas and clean water. The feed stream would be 21,888 wet tons per day at $13.7 \%$ solids. This would 
allow the removal of the entire evaporation train and downstream waste processing. This could have further implications with water and heat balances that need to be explored.

Replacement of all downstream equipment with wet gasification is expected to require an installed equipment cost of \$24M and a Total Capital Investment (TIC) of \$143M. Annual operating costs are expected to be about $\$ 33 \mathrm{M}$. This gives a breakeven gas cost of \$2.24/MMBtu. Unfortunately, this does not account for any of the substantial changes that would have to be made to the flowsheet.

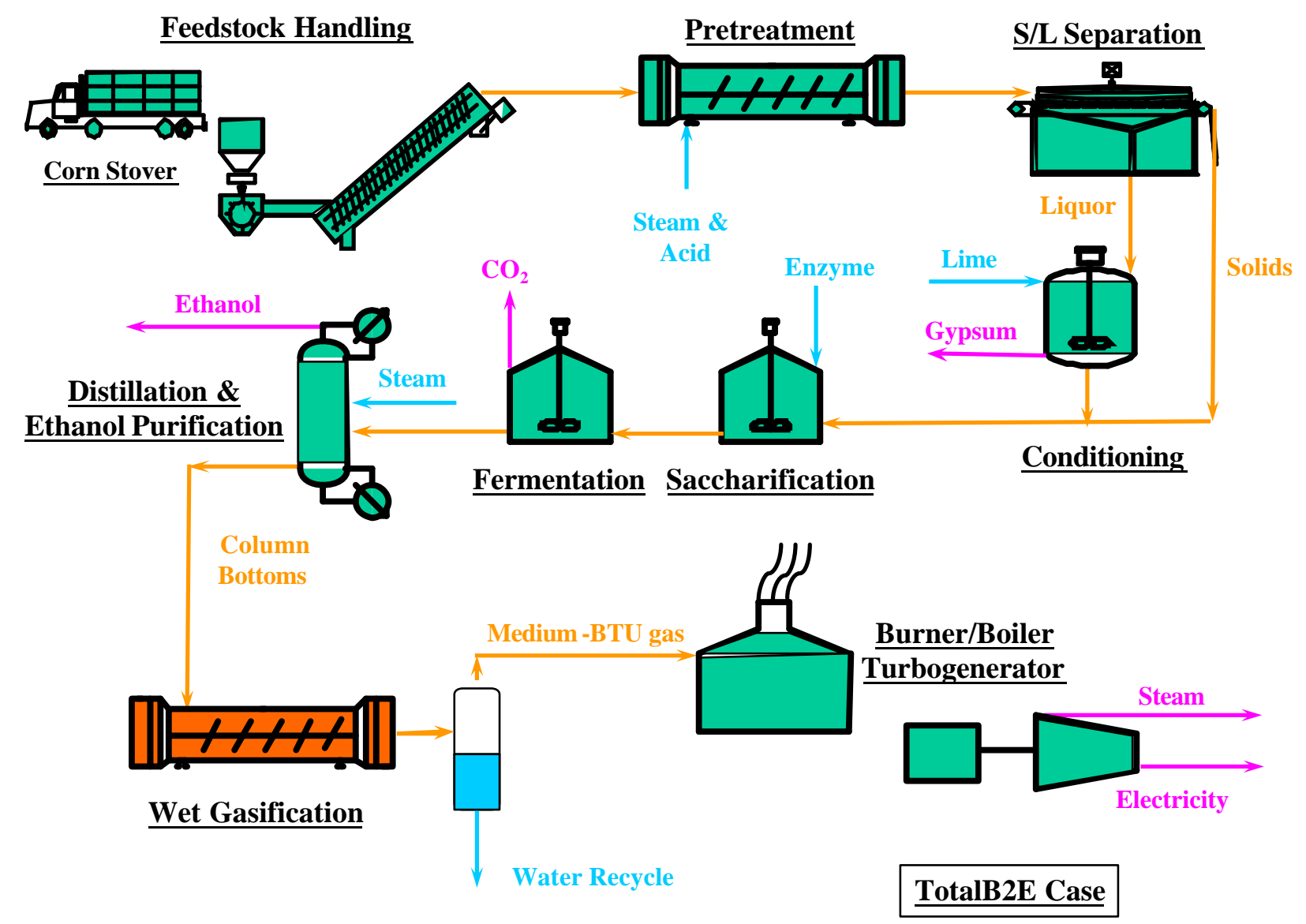

Figure 5. Flow schematic of the TotalB2E case 


\section{Equipment Summary}

For the DDG\&S-PNNL case, the following wet gasification equipment is identified. The equipment items will be similar for all cases, but the purchased costs will be scaled to the specific feed streams.

Table 2. Major equipment items in wet gasification - costs shown for DDG\&S-PNNL case

\begin{tabular}{lr}
\hline \multicolumn{1}{c}{ System/Equipment } & Purchase Cost (\$K) * \\
\hline & \\
Reactor Vessel(s) 2 ea, 6'dia x 28' long, 3000 psig, & 1977 \\
350C, LHSV=1.6 & 112 \\
High Pressure Pump + Spare & 1000 \\
Heater & 743 \\
Heat Exchanger & 100 \\
Separator & 200 \\
Feed Tank & 200
\end{tabular}




\section{Capital and Operating Costs}

Total direct costs (TDC) are developed by scaling from the total purchased equipment costs.

Other direct costs also include instrumentation and controls, installed piping, installed electrical, the cost of buildings, site preparation, and the cost of land. The following table lists the TDC for the DDGS-NREL flowsheet. Peters and Timmerhaus (1968) summarize typical values for both direct and indirect costs of solid processing plants, of solid-fluid processing plants, and of fluid processing plants. Since this processing plant is a solid-fluid plant, these percentage costs were developed by interpolating closely around the solid-fluid costs. The ratios for both the direct and indirect costs are based upon standard estimates for a grassroots plant at an undeveloped site. Since such a plant would presumably be sited on an existing site, some allowances can be made for land costs.

Table 3. Total Direct Costs for wet gasification - costs shown for DDG\&S-NREL case

\begin{tabular}{lccc}
\multicolumn{1}{c}{ Item } & $\begin{array}{l}\text { \% of Purchased } \\
\text { Equipment Cost } \\
\text { (Typical Ranges) }\end{array}$ & $\begin{array}{c}\text { \% of Purchased } \\
\text { Equipment Costs }\end{array}$ & Cost, \$K \\
\hline $\begin{array}{l}\text { Direct Costs } \\
\begin{array}{l}\text { Purchased Equipment } \\
\text { (delivered) }\end{array}\end{array}$ & 100 & 100 & 4132 \\
$\begin{array}{l}\text { Equipment Installation } \\
\text { Insulation (installed) }\end{array}$ & 0 to 9 & 75 & 2273 \\
$\begin{array}{l}\text { Instrumentation and Controls } \\
\text { (installed) }\end{array}$ & 6 to 30 & 20 & 826 \\
$\begin{array}{l}\text { Piping (installed) } \\
\text { Electrical (installed) }\end{array}$ & 16 to 66 & 40 & 1653 \\
$\begin{array}{l}\text { Buildings (including services) } \\
\text { Site Preparation, Yard }\end{array}$ & 10 to 11 & 10 & 1943 \\
$\begin{array}{l}\text { Improvements } \\
\text { Services/Support Facilities } \\
\text { (utilities and distributions } \\
\text { systems, waste management, } \\
\text { communications) }\end{array}$ & 45 to 68 & 47 & 537 \\
$\begin{array}{l}\text { Land Costs } \\
\text { Total Direct Costs (TDC) }\end{array}$ & 10 to 13 & 13 & 2273 \\
\hline
\end{tabular}


Total indirect costs (TIC), as listed in Table 4, typically include the cost of engineering and construction expenses that cannot be directly tied to specific pieces of equipment or bricks and mortar. Again, they are estimated as a percentage of the total direct costs as outlined in Peters and Timmerhaus (1968) for solid-liquid processing plants. Estimates of these percentages were compiled from a study of fixed capital investment from over 100 chemical process projects, many at the $95 \%$ confidence level.

Table 4. Total Indirect Costs for wet gasification - costs shown for DDG\&S-NREL case

\begin{tabular}{lccc}
\hline Indirect Costs (TIC) & $\begin{array}{c}\text { Basis Used for } \\
\text { Analysis }\end{array}$ & $\begin{array}{c}\text { Percentage of } \\
\text { Purchased Equip }\end{array}$ & $\mathbf{2 6 1 1}$ \\
\hline Engineering & 8\% of TDC & $28 \%$ & 1160 \\
Construction Expenses & $10 \%$ of TDC & $35 \%$ & 1450
\end{tabular}

Although technically considered part of the indirect costs, the contractors fee, contingency, and startup expenses are calculated after the direct and indirect plant costs are totaled as shown in Table 5. Typical contractor fees vary widely, depending on the complexity of the job. A midrange contractor's fee of 5\% was assumed. The wet gasification plant will be the first of its kind in the U.S., and ample allocations for both contingency and startup are warranted.

Table 5. Other costs for wet gasification - costs shown for DDG\&S-NREL case

\begin{tabular}{lccc}
\hline $\begin{array}{l}\text { Total Direct and Indirect } \\
\text { Costs (TDC + TIC) }\end{array}$ & $\mathbf{4 1 4 \%}$ & $\mathbf{1 7 1 1 4}$ \\
\hline $\begin{array}{l}\text { Contractors Fee (typical range } \\
\text { is 2\% to 8\% of TDC + TIC) }\end{array}$ & $5 \%$ of TDC + TIC & $21 \%$ & 856 \\
$\begin{array}{l}\text { Contingency (typical range is } \\
5 \% \text { to } 15 \% \text { of TDC + TIC) }\end{array}$ & $10 \%$ of TDC + TIC & $41 \%$ & 1711 \\
$\begin{array}{l}\text { Startup Expenses (typical } \\
\text { range is } 8 \% \text { to } 10 \% \text { of FCl) }\end{array}$ & $10 \%$ of TDC + TIC & $41 \%$ & 1711 \\
\hline
\end{tabular}

The Total Capital Investment (TCI) as shown in Table 6, includes both the FCI plus the working capital. Working capital is the money invested in raw materials, product in inventory, accounts receivable, cash on hand for operating expenses (i.e., salaries, supplies), accounts payable, and taxes. For plants that operate year-round, the working capital is typically equivalent to the production costs for 1 month of operations. Peters and Timmerhaus (1968) state the initial working capital required for most chemical plants ranges from $10 \%$ to $20 \%$ of the TCI. Therefore, for this analysis, it has been assumed that required working capital will be about $15 \%$ of the TCI. 
Table 6. Total Capital Investment for wet gasification - costs shown for DDG\&S-NREL case

\begin{tabular}{llcc}
\hline Fixed Capital Investment (FCl) & $\mathbf{5 1 8 \%}$ & $\mathbf{2 1 3 9 3}$ \\
\hline $\begin{array}{l}\text { Working Capital (typical range } \\
\text { is 10\% to 20\% of TCl) }\end{array}$ & $15 \%$ of FCl & $\mathbf{7 8 \%}$ \\
& & & \\
\hline Total Capital Investment (TCl) & $\mathbf{5 9 5 \%}$ & $\mathbf{2 4 6 0 2}$ \\
& & \\
\hline
\end{tabular}

Operating costs, found in Table 7 for the gasification plant, include a few utilities, process labor, catalyst costs, maintenance, and overheads. For the DDGS-NREL base case, which includes a zero feedstock cost, they are about $\$ 5.5 \mathrm{M}$. 
Table 7. Operating costs for wet gasification - costs shown for DDG\&S-NREL case

\begin{tabular}{|c|c|c|c|c|}
\hline Item & Unit & $\begin{array}{c}\text { Unit Cost, } \\
\$ / \text { unit }\end{array}$ & $\begin{array}{c}\text { Number of } \\
\text { Units Per Year }\end{array}$ & $\begin{array}{r}\text { Annual Cost, } \\
\$ K / y r\end{array}$ \\
\hline \multicolumn{5}{|l|}{ Raw Materials } \\
\hline$\overline{D D G}$ & wet tons/yr & $\$$ & 693,000 & 0 \\
\hline Utilities & & & & 342 \\
\hline Electricity & kWh & $\$$ & $5,760,000$ & 173 \\
\hline Natural Gas & $\mathrm{ft}^{3}$ & & & 169 \\
\hline Diesel Fuel & gal & $\$$ & & 0 \\
\hline Water & metric ton & $\begin{array}{c}\$ \\
0.50\end{array}$ & & 0 \\
\hline Labor & & & & 360 \\
\hline Supervisors & hour & $\begin{array}{c}\$ \\
40.00\end{array}$ & & 0 \\
\hline Operators & hour & $\begin{array}{c}\$ \\
30.00\end{array}$ & 12,000 & 360 \\
\hline Special Maintenance Items & & & & 872 \\
\hline Catalyst Replacement & $\mathrm{Cuft}$ & & & 1,534 \\
\hline Catalyst Credit & & & & -662 \\
\hline Other Overheads and Indirects & & & & 4017 \\
\hline $\begin{array}{l}\text { Direct Supervision and Clerical } \\
\text { (15\% of labor) }\end{array}$ & 54 & & & \\
\hline $\begin{array}{l}\text { Maintenance and Repairs ( } 5 \% \text { of } \\
\text { FCl) }\end{array}$ & 1070 & & & \\
\hline $\begin{array}{l}\text { Operating Supplies ( } 15 \% \text { of } \\
\text { maintenance) }\end{array}$ & 160 & & & \\
\hline $\begin{array}{l}\text { Plant Overhead Costs ( } 40 \% \text { of } \\
\text { labor, supervision and } \\
\text { maintenance) }\end{array}$ & 593 & & & \\
\hline $\begin{array}{l}\text { Plant Depreciation and Interest } \\
\text { Charges ( } 7 \% \text { of } \mathrm{FCl} / \text { year) }\end{array}$ & 1497 & & & \\
\hline Property Tax ( $2 \%$ of $\mathrm{FCI} /$ year) & 428 & & & \\
\hline Insurance ( $1 \%$ of $\mathrm{FCl} /$ year) & 214 & & & \\
\hline
\end{tabular}




\section{Economic Summary}

Table 8 summarizes the DDG\&S-NREL case economic summary.

Table 8. Cost summary for the DDG\&S-NREL case

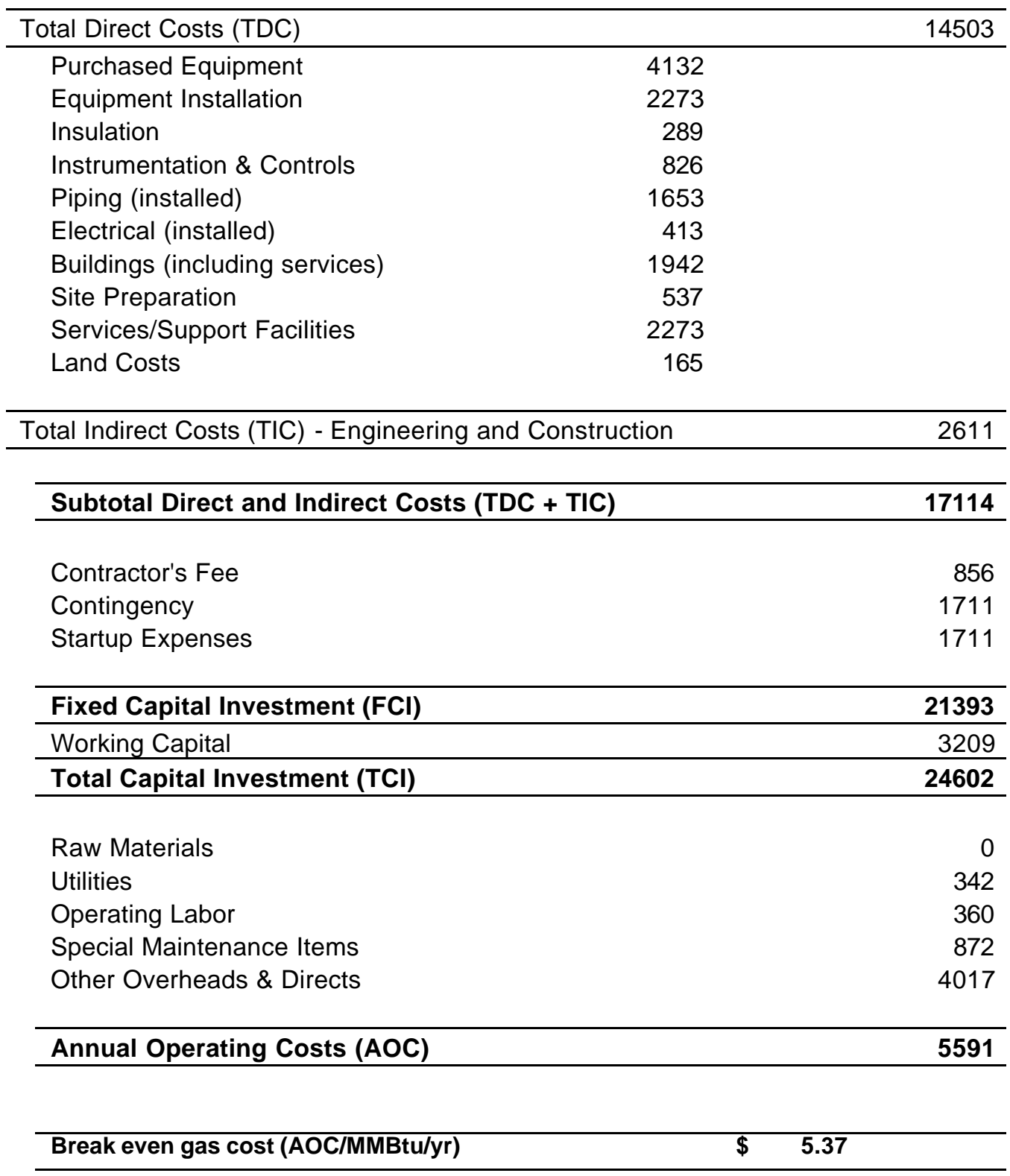




\section{Sensitivity Analysis}

For the DDG\&S-NREL case, a preliminary sensitivity analysis was conducted to determine the relative effects of plant size, feedstock value, and gas cost on the Return on Investment (ROI) possible for the wet gasification process.

At the baseline case of 25MMgal fuel ethanol per year, ROI was a dismal $-12.8 \%$ assuming $\$ 2.5 /$ million Btu gas price. Even given a zero feedstock cost (a highly unlikely situation with DDG\&S), a gas cost of $\$ 2.50 / \mathrm{MMBtu}$ could not be achieved until the plant size was nearly $75 \mathrm{MMgal}$ of fuel ethanol per year, similar to the DDG\&S-PNNL case.

If a tipping fee was allowed on the DDG\&S, for each $\$ 2 /$ wet ton, the ROI increased by approximately $5 \%$, and was positive at about $\$ 5 /$ wet ton for the baseline case. We must remember that typical DDG\&S sells for approximately \$90/dry ton. If we assume that DDGS is about $10 \%$ solids as produced, this is $\$ 9 /$ wet ton value. If one has an efficient filter press and dryer a dried product can probably be produced at slightly less than this. If DDGS drops to $\$ 50 /$ ton or less, the ethanol producer would be paying more to dry than the value of the product.

By varying the fuel gas cost, one can achieve some measure of profitability. For the baseline case, the breakeven point was $\$ 5.37$ per MMBtu. These effects of plant size and feedstock costs on breakeven gas production cost are seen in Figure 6.

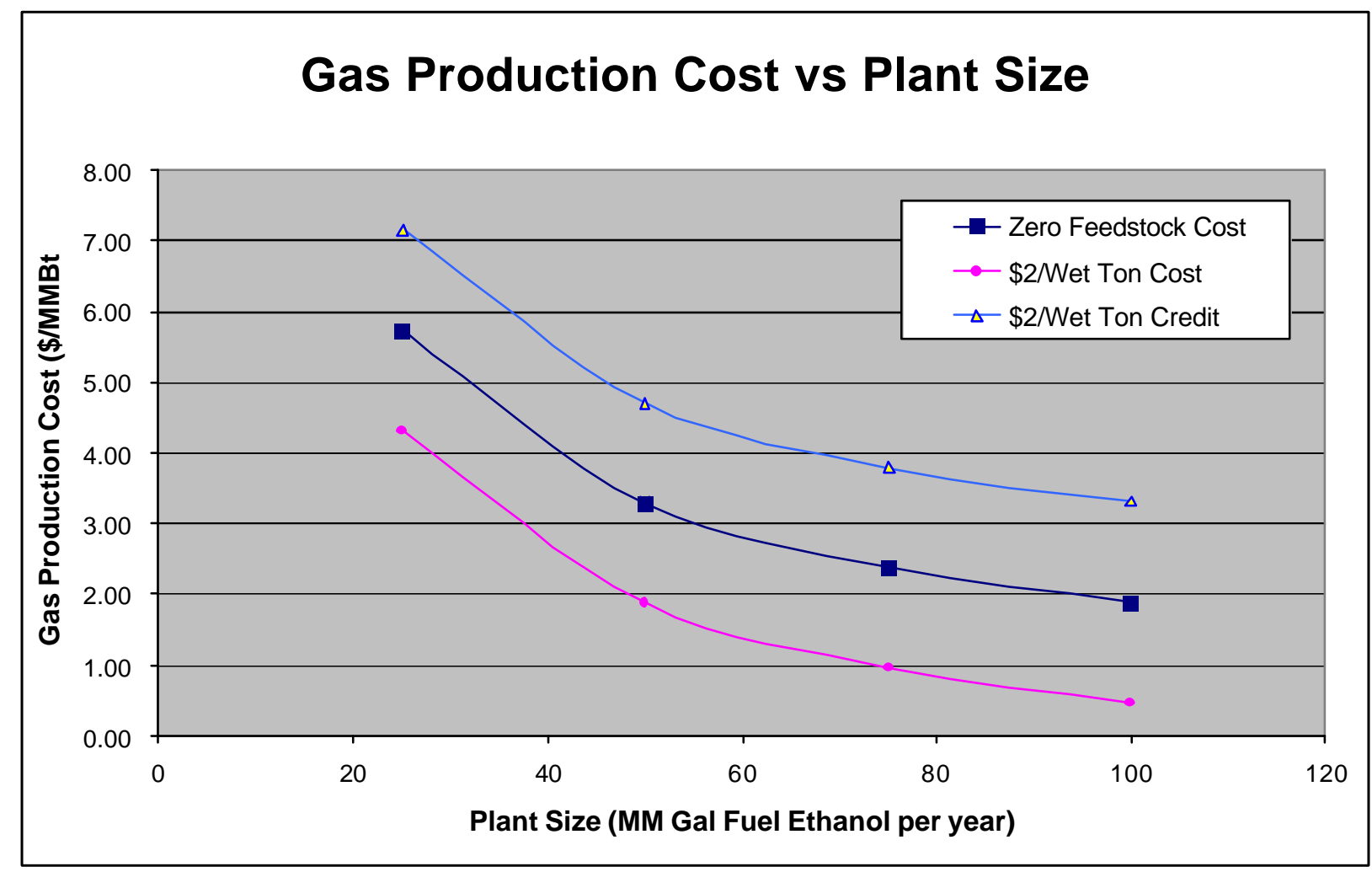

Figure 6. Gas production cost as a function of plant size, assuming different gas costs 
Table 9 presents some of the detailed costs for the various sized plants considered in these sensitivity studies and the calculated rates of return for each plant. Tables 10 and 11 have similar data and calculated rates of return as a function of cost of feedstock and value of gas product.

Table 9. Effect of Plant Size on Rate of Return

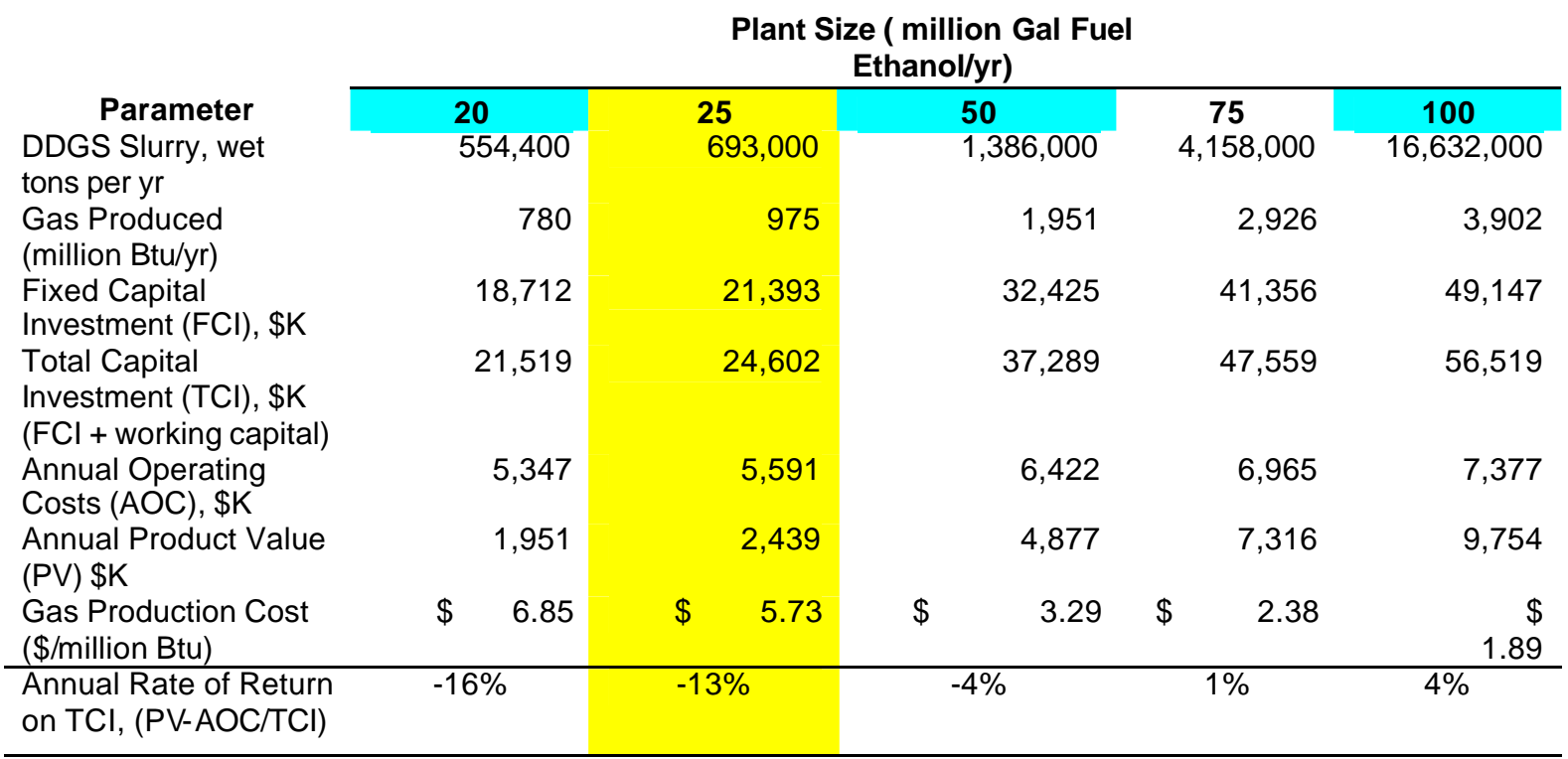

* BASELINE

Tables 12 through 15 provide similar costs and calculated breakeven gas costs as a function of DDG\&S costs for the four sizes of plant considered in these sensitivities. 


\section{Table 10. Effect of Cost of DDGS on Rate of Return ${ }^{(a)}$ for the DDG\&S-NREL case}

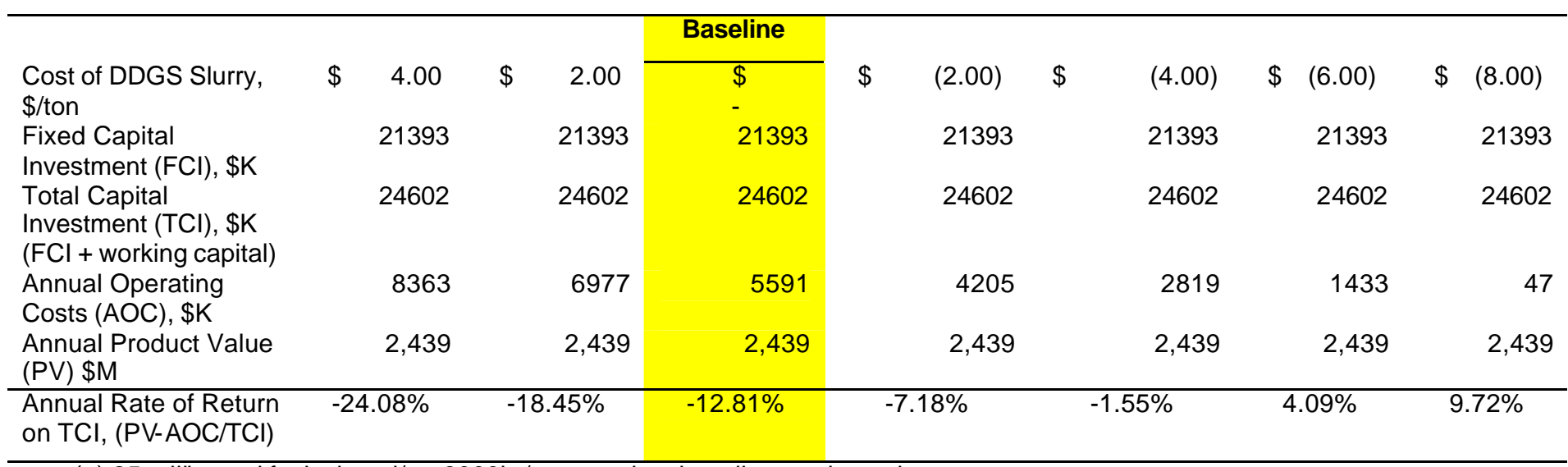

(a) 25 million gal fuel ethanol/yr- 8000hr/yr operation, baseline product prices

Table 11. Effect of Gas Prices on Rate of Return for the DDG\&S-NREL case

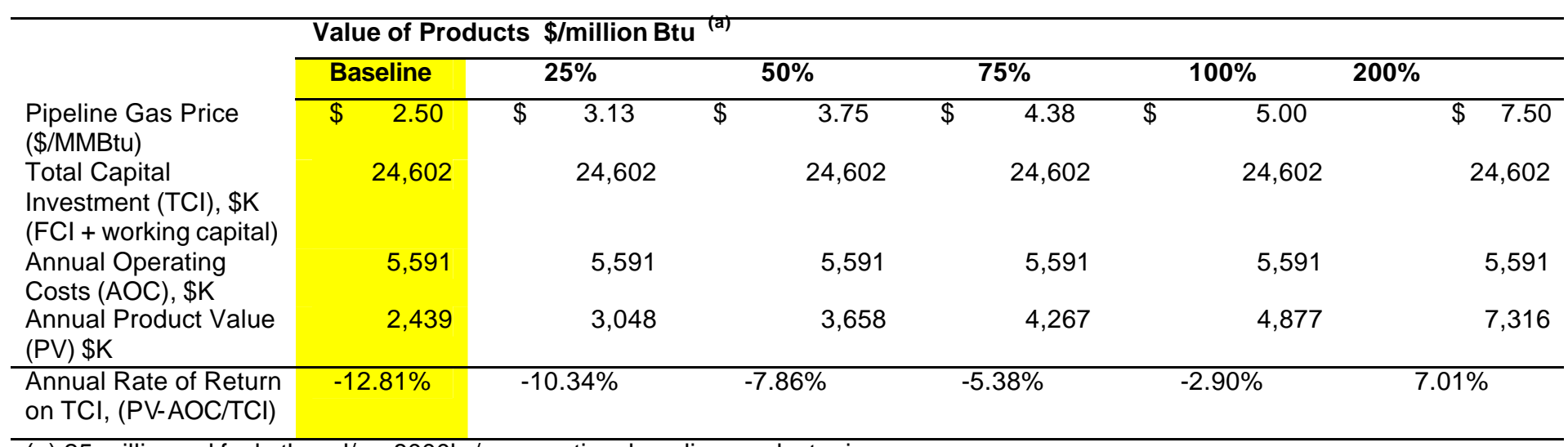

(a) 25 million gal fuel ethanol/yr- 8000hr/yr operation, baseline product prices 
Table 12. Cost to Produce Gas vs DDGS Cost (25 million gal/yr)

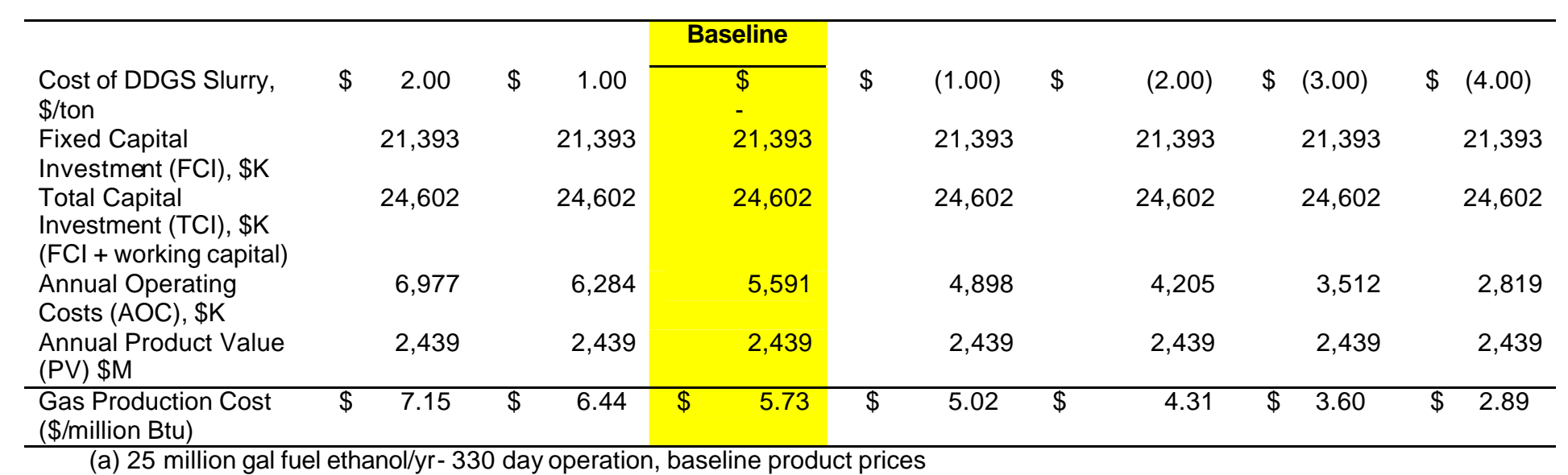

(a) 25 million gal fuel ethanol/yr - 330 day operation, baseline product prices

Table 13. Cost to Produce Gas vs DDGS Cost (50 million gal/yr)

\begin{tabular}{|c|c|c|c|c|c|c|c|c|c|c|c|c|c|}
\hline & & & & & Baseline & & & & & & & & \\
\hline $\begin{array}{l}\text { Cost of DDGS Slurry, } \\
\$ / \text { ton }\end{array}$ & $\$$ & 2.00 & $\$$ & 1.00 & $\$$ & $\$$ & $(1.00)$ & $\$$ & $(2.00)$ & $\$$ & $(3.00)$ & $\$$ & $(4.00)$ \\
\hline $\begin{array}{l}\text { Fixed Capital } \\
\text { Investment (FCl), \$K }\end{array}$ & & 32,425 & & 32,425 & 32,425 & & 32,425 & & 32,425 & & 32,425 & & 32,425 \\
\hline $\begin{array}{l}\text { Total Capital } \\
\text { Investment (TCI), \$K } \\
\text { (FCI + working capital) }\end{array}$ & & 37,289 & & 37,289 & 37,289 & & 37,289 & & 37,289 & & 37,289 & & 37,289 \\
\hline $\begin{array}{l}\text { Annual Operating } \\
\text { Costs }(A O C), \$ K\end{array}$ & & 9,194 & & 7,808 & 6,422 & & 5,036 & & 3,650 & & 2,264 & & 878 \\
\hline $\begin{array}{l}\text { Annual Product Value } \\
\text { (PV) \$M }\end{array}$ & & 4,877 & & 4,877 & 4,877 & & 4,877 & & 4,877 & & 4,877 & & 4,877 \\
\hline $\begin{array}{l}\text { Gas Production Cost } \\
\text { (\$/million Btu) }\end{array}$ & $\$$ & 4.71 & $\$$ & 4.00 & 3.29 & $\$$ & 2.58 & $\$$ & 1.87 & $\$$ & 1.16 & $\$$ & 0.45 \\
\hline
\end{tabular}

(b) 50 million gal fuel ethanol/yr 330 day operation, baseline product prices 


\section{Table 14. Cost to Produce Gas vs DDGS Cost (75 million gal/yr)}

\begin{tabular}{|c|c|c|c|c|c|c|c|c|c|c|c|c|c|c|}
\hline & & & & & & eline & & & & & & & & \\
\hline $\begin{array}{l}\text { Cost of DDGS Slurry, } \\
\$ / \text { ton }\end{array}$ & $\$$ & 2.00 & $\$$ & 1.00 & $\$$ & - & $\$$ & $(1.00)$ & $\$$ & $(2.00)$ & $\$$ & $(3.00)$ & $\$$ & $(4.00)$ \\
\hline $\begin{array}{l}\text { Fixed Capital } \\
\text { Investment (FCI), \$K }\end{array}$ & & 41,356 & & 41,356 & & 41,356 & & 41,356 & & 41,356 & & 41,356 & & 41,356 \\
\hline $\begin{array}{l}\text { Total Capital } \\
\text { Investment (TCI), \$K } \\
\text { (FCl + working capital) }\end{array}$ & & 47,559 & & 47,559 & & 47,559 & & 47,559 & & 47,559 & & 47,559 & & 47,559 \\
\hline $\begin{array}{l}\text { Annual Operating } \\
\text { Costs (AOC), \$K }\end{array}$ & & 11,123 & & 9,044 & & 6,965 & & 4,886 & & 2,807 & & 728 & & $-1,351$ \\
\hline $\begin{array}{l}\text { Annual Product Value } \\
\text { (PV) \$M }\end{array}$ & & 7,316 & & 7,316 & & 7,316 & & 7,316 & & 7,316 & & 7,316 & & 7,316 \\
\hline $\begin{array}{l}\text { Gas Production Cost } \\
(\$ / \text { million Btu) }\end{array}$ & $\$$ & 3.80 & $\$$ & 3.09 & $\$$ & 2.38 & $\$$ & 1.67 & $\$$ & 0.96 & $\$$ & 0.25 & $\$$ & $(0.46)$ \\
\hline
\end{tabular}

(c) 75 million gal fuel ethanol/yr 330 day operation, baseline product prices

Table 15. Cost to Produce Gas vs DDGS Cost (100 million gal/yr) ${ }^{\mathrm{d}}$

\begin{tabular}{|c|c|c|c|c|c|c|c|c|c|c|c|c|c|c|}
\hline & & & & & & eline & & & & & & & & \\
\hline $\begin{array}{l}\text { Cost of DDGS Slurry, } \\
\$ / \text { ton }\end{array}$ & $\$$ & 2.00 & $\$$ & 1.00 & $\$$ & - & $\$$ & $(1.00)$ & $\$$ & $(2.00)$ & $\$$ & $(3.00)$ & $\$$ & $(4.00)$ \\
\hline $\begin{array}{l}\text { Fixed Capital } \\
\text { Investment (FCl), \$K }\end{array}$ & & 49,147 & & 49,147 & & 49,147 & & 49,147 & & 49,147 & & 49,147 & & 49,147 \\
\hline $\begin{array}{l}\text { Total Capital } \\
\text { Investment (TCI), \$K } \\
\text { (FCl + working capital) }\end{array}$ & & 56,519 & & 56,519 & & 56,519 & & 56,519 & & 56,519 & & 56,519 & & 56,519 \\
\hline $\begin{array}{l}\text { Annual Operating } \\
\text { Costs }(A O C), \$ K\end{array}$ & & 12,921 & & 10,149 & & 7,377 & & 4,605 & & 1,833 & & -939 & & $-3,711$ \\
\hline $\begin{array}{l}\text { Annual Product Value } \\
\text { (PV) } \$ M\end{array}$ & & 9,754 & & 9,754 & & 9,754 & & 9,754 & & 9,754 & & 9,754 & & 9,754 \\
\hline $\begin{array}{l}\text { Gas Production Cost } \\
\text { (\$/million Btu) }\end{array}$ & $\$$ & 3.31 & $\$$ & 2.60 & $\$$ & 1.89 & $\$$ & 1.18 & $\$$ & 0.47 & $\$$ & $(0.24)$ & $\$$ & $(0.95)$ \\
\hline
\end{tabular}

(\$/million Btu)

(d) 100 million gal fuel ethanol/yr - 330 day operation, baseline product prices 


\section{References}

Elliott et al (1999). "Chemical Processing in High-Pressure Aqueous Environments. 6. Demonstration of Catalytic Gasification for Chemical Manufacturing Wastewater Cleanup in Industrial Plants," Industrial \& Engineering Chemistry Research, Vol 38, No. 3, pp.879-883.

Peters \& Timmerhaus (1968). Plant Design and Economics for Chemical Engineers, $2^{\text {nd }}$ Edition, McGraw-Hill Book Company, New York, New York. 